\title{
REFERENCES
}

Black, J. N. (1963). Aust. F. agric. Res. 14, 20.

Black, J. N. \& Watson, D. J. (I960). Field Crop Abstr. 13, I69.

Blackman, G. E. \& Black, J. N. (1959). Ann. Bot. NS 23, I3I.

Bonner, J. (1962). Science, ז37, I1.

Borden, R. J. (I945). Hawaii. Plant. Rec. 49, 259.

Boysen Jensen, P. (1932). Die Stoffproduktion der Pflanzen. Jena: G. Fischer Verlag.

Brougham, R. W. (1956). Aust. F. agric. Res. 7, 377.

Davidson, J. L. \& Donald, C. M. (1958). Aust. F. agric. Res. 9, 53.

Donald, C. M. (1951). Aust. F. agric. Res. 2, 355.

Donald, C. M. \& Black, J. N. (1958). Herb. Abstr. 28, 1.

Harper, P. (1963). Nature, Lond., 197, 917.

Kanda, M. \& Sato, F. (1963). Sci. Rep. Res. Inst. Tohoku Univ. Ser. D, 14, 57.

Loomis, R. S. \& Williams, W. A. (1963). Crop Sci. 3, 67.

Monsi, M. \& Saeki, T. (1953). Fap. F. Bot. 14, 22.

Nichiporovich, A. A. (1954). Photosynthesis and the Theory of Obtaining High Crop Yields. (In Russian). Moscow: USSR Academy of Sciences.

Penman, H. L. (1958). In The Biological Productivity of Britain, p. 9I. [W. B. Yapp and D. J. Watson, editors.] London: The Institute of Biology.

Rees, A. R. (1 963). Nature, Lond., r97, 63.

Stern, W. R. \& Donald, C. M. (1961). Nature, Lond., 189, 597.

Takeda, T. (I96r). fap. f. Bot. I7, 403.

Watson, D. J. (1947). Ann. Bot. NS II, 4I.

Watson, D. J. (1952). Advanc. Agron. 4, ror.

Watson, D. J. (I958). Ann. Bot. NS 22, 37.

\section{Irrigation as a factor in boosting food and fibre production}

\author{
By H. Olivier, Sir Alexander Gibb and Partners, Telford House, London, SW r
}

\section{Introduction}

Irrigation is an ancient practice dating back to before the dawn of history. Egypt claims to have the oldest dam, built 5000 years ago, to store water for drinking and irrigation. Indications are that sophisticated irrigation schemes existed in the lower Euphrates Valley 4000-6000 years ago. Wells, tanks and inundation canals were sources of irrigation in China, India and Pakistan thousands of years ago.

The industrial revolution of Europe was basically responsible for the great upsurge of irrigation developments during the nineteenth century when it is estimated that world irrigated areas increased from 20 million to 100 million acres (Gulhati, I958). New inventions, discoveries, mechanization and improved communications resulted in great redistributions of population: from rural to urban areas and from country to country. The effects of recurring droughts and famines on populations depending on rain or river-flood agriculture were observed, reported, and interpreted and there followed an increasing awareness of the meaning of the term 'relative standards of living'. 'The new tools of science were applied to the agricultural sector and to the conception and construction of large-scale perennial irrigation schemes such as the classic projects of Egypt, India, Pakistan and Iraq. The agricultural sector began to develop its own industrial 'wing' by the production of fibre (cash) crops as distinct from food (subsistence) crops. 
During the first half of this century the pace of irrigation expansion increased rapidly. It is estimated that some 400 million acres are under irrigation at present. The distribution by countries is shown in Table $\mathrm{I}$, from which it is seen that China, India and Pakistan between them account for approximately two-thirds of the world irrigated acreage or about eight times the area irrigated in the USA.

Table I. Principal irrigation areas of the world: land receiving water by irrigation schemes excluding inundation areas 1957-61 ( $F A O$, 1962)

$\begin{array}{clc}\text { Order } & \text { Country } & \text { Acres } \times 10^{-6} \\ \text { I } & \text { China } & 183 \cdot 0 \\ 2 & \text { India } & 58 \cdot 0 \\ 3 & \text { USA } & 37 \cdot 7 \\ 4 & \text { Pakistan } & 27 \cdot 4 \\ 5 & \text { Russia } & 17 \cdot 8 \\ 6 & \text { Indonesia } & 14 \cdot 8 \\ 7 & \text { Iran } & 11 \cdot 6 \\ 8 & \text { Mexico } & 10 \cdot 4 \\ 9 & \text { Iraq } & 9 \cdot 1 \\ \text { I0 } & \text { Japan } & 8 \cdot 4 \\ \text { I I } & \text { Egypt } & 6 \cdot 1 \\ \text { I2 } & \text { Turkey } & 4 \cdot 9 \\ \text { I3 } & \text { Spain } & 4 \cdot 6 \\ \text { I4 } & \text { Thailand } & 4 \cdot 1 \\ \text { I5 } & \text { Argentina } & 3 \cdot 7\end{array}$

Order
16
17
18
19
20
21
22
23
24
25
26
27
28
29
30

Country
Chile
Peru
Korea
Australia
Philippines
Sudan
Madagascar
Viet Nam
South Africa
Syria
Morocco
Burma
Colombia
Formosa
Greece

Acres $\times 10^{-6}$
$3 \cdot 5$
$3 \cdot 0$
$3 \cdot 0$
$2 \cdot 1$
$2 \cdot 0$
$2 \cdot 0$
$I \cdot 8$
$1 \cdot 5$
$I \cdot 5$
$1 \cdot 4$
$1 \cdot 3$
$I \cdot 3$
$I \cdot 2$
$1 \cdot 2$
$I \cdot 1$

The scale of global irrigation developments and its relationship to multipurpose planning has intensified the awareness of pressures of future needs in the light of limited water and land resources, and is achieving the desirable closer collaboration between agriculturalists, engineers, scientists, economists and financiers with regard to the conception, design, financing and execution of projects.

Among immediate by-products has been the increasing effect of the application, to project formulation and operation, of global as distinct from local experience. Corollary effects are the tendency for critical examination of irrigation efficiencies (Olivier, I963) and the concerted efforts being made to establish meaningful and effective criteria for the assessment of economic viability of projects (Kutilla \& Eckstein, I957; McKean, I958).

\section{The irrigation factor in boosting crop production}

Irrigation is but one factor in the process of crop production, others being the nature of the soil, pest control, farming techniques, the use of fertilizers, crop types and rotations.

Recent findings reported by the US Agricultural Research Service (Beauchamp, I958) are to the effect that research ceilings of production per acre under the latter headings have levelled off in recent years, still leaving a substantial gap of approximately $50 \%$ between the level of production per unit possible through full application of science and the actual current level of production per unit on the farms. The conclusion is that, particularly in the areas previously regarded as humid, the next advance must come from both increased and more efficient irrigation. 
Practical difficulties confront the implementation of such conclusions. Against increased production from new irrigation areas in the overall balance sheet there must be offset steady losses of production from agricultural areas going out of use. According to recent surveys, Pakistan loses annually some 100000 acres of agricultural land because of increasing waterlogging and salinity of soils. The corresponding annual loss of land in the USA due to development projects like housing, roads and airports and from soil deterioration is estimated at $\mathbf{I} \cdot 3$ million acres.

Similarly, owing to increasing competition for limited water resources from other sectors (domestic, industrial and power generation) account has to be taken of potential re-use of water, i.e. degree of consumptive use when assessing benefits likely to accrue from increased irrigation efficiencies. At present, in the USA water requirements for industry and irrigation are about equal-but, whereas industrial use is only $2 \%$ consumptive, irrigation use is $60 \%$ consumptive.

One result of such considerations has been intensified investigations of the possibilities of stabilizing agriculture in the 'humid' zones by 'supplementary irrigation'. Recent researches have made it possible to prepare reasonably reliable assessments of regional 'drought' characteristics in terms of soil storage capacities, rates of water requirements per unit cropland and effective rainfall.

Refinements of these design tools and improvements in the accuracy of the necessary water balance sheets can be achieved only through greater understanding of the factors controlling the effectiveness of rainfall. The cardinal factor is the time element.

Overall irrigation efficiency is controlled not by one but by three distinct laws of hydraulics. On the supply or credit side there are the hydraulics of conveyance and of application. With the former, the classical laws of hydraulics for conduits such as canals and pipes pertain. With the latter multidirectional rates of movement are dependent on plant populations and on surface and permeability characteristics of individual soils and are not necessarily directly proportional either to head or pressure or to rate and amount of supply, whether by irrigation or precipitation. Resultant or effective rainfall at the root zone is a complex integration of two hydrographs analogous to the attenuation achieved by routing flood inflows through two reservoirs in series. The first modification of gross input intensities is achieved by leaf interception and mulches, and the second by the permeability of the soils within the root zone.

The final criterion of efficiency is that rate of demand should closely match the rate of supply. It is only comparatively recently that research has resulted in the formulation of laws governing the rates of demand (or use) from cropsoil units. Average potential evapotranspiration curves can now be prepared for different localities on a monthly basis using simple climatic data observed at most second order meteorological stations. A typical set of such curves, for widely separated and climatically different regions, is illustrated in Fig. I.

Practical applications of these laws of hydraulics have served to show that total rainfall, within a given period, is not by itself a measure of effective availability for crop use, and hence cannot be used reliably for assessment of supplementary irrigation supplies. 


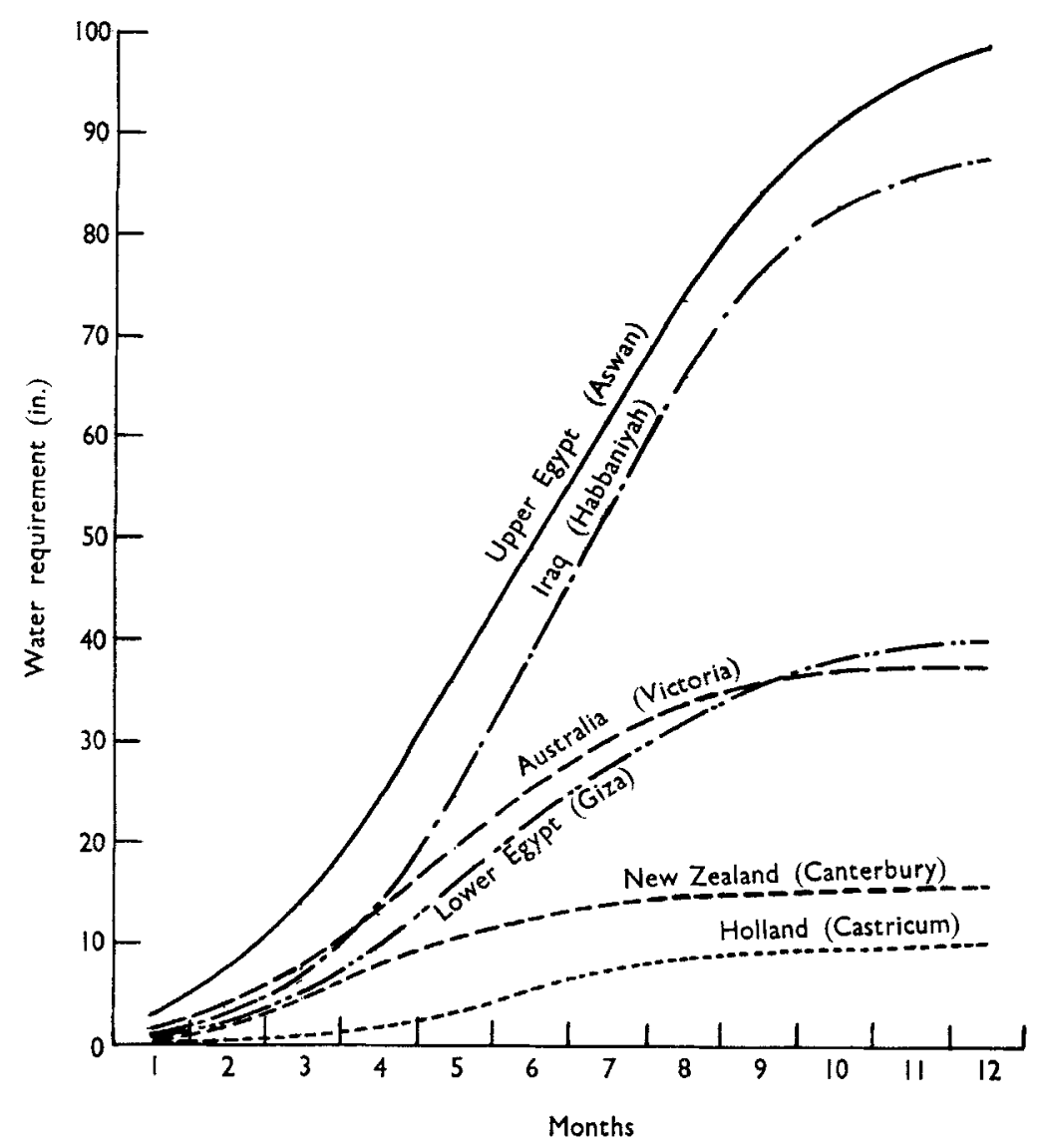

Fig. 1. Typical curves for mean annual characteristic water requirement of cropland.

\section{Effectiveness of supplemental irrigation}

It is a very difficult matter to assess reliably exactly the beneficial physical and financial effects of irrigation because all the other influence factors come into play. Indeed, fertilizer is often applied best because of, and by, irrigation. However, if we accept that in the arid regions production is not possible at all without irrigation and that in the humid regions recent statistics on a 'with' and 'without' basis will have taken into account much of the advances made in farming techniques under other headings before the application of supplemental irrigation water, then the general conclusions reached by Government or private research organizations provide a reasonably reliable correlation between irrigation and benefits. The following examples illustrate the trends observed in England and the USA.

Results from trials at Woburn, Gleadthorpe and West Midlands for maincrop potatoes have been summarized by Nix \& Prickett (196r) and are quoted in Table 2.

Of particular interest are the large increases obtained in the dry years, 1955 and 1959, and the small or negative response (except in the West Midlands) in 1956, I957 and 1958 . On the light gravel at Gleadthorpe, the mean increase over 5 years 
Table 2. Results of irrigation for maincrop potatoes (Nix \& Prickett, 196x)

\begin{tabular}{|c|c|c|c|c|c|}
\hline \multirow[b]{2}{*}{ Place } & \multirow[b]{2}{*}{ Year } & \multirow{2}{*}{$\begin{array}{l}\text { Yield without } \\
\text { irrigation } \\
\text { (tons/acre) }\end{array}$} & \multicolumn{2}{|c|}{ Increase from irrigation } & \multirow{2}{*}{$\begin{array}{l}\text { Irrigation } \\
\text { applied } \\
\text { (in.) }\end{array}$} \\
\hline & & & tons/acre & $\%$ & \\
\hline \multirow[t]{3}{*}{ Woburn } & I954 & $16 \cdot 0$ & -0.9 & -6 & $2 \cdot 2$ \\
\hline & I 955 & I I $\cdot \mathbf{I}$ & $9 * 3$ & 83 & $6 \cdot 3$ \\
\hline & 1956 & 14.9 & 0.5 & 3 & 0.5 \\
\hline \multirow[t]{5}{*}{ Gleadthorpe } & 1955 & $5 \cdot 0$ & 6.4 & ${ }_{13} 8$ & 6 \\
\hline & $195^{6}$ & No & igation neede & & \\
\hline & I 957 & $8 \cdot 0$ & 0.5 & 6 & $\mathbf{I}$ \\
\hline & $195^{8}$ & $8 \cdot 0$ & -0.6 & -8 & 2 \\
\hline & 1959 & $7 \cdot 5$ & $10 \cdot I$ & I 35 & 8 \\
\hline \multirow[t]{5}{*}{ West Midlands } & I955 & & 8 & & 4 \\
\hline & 1956 & & 5 & & 2 \\
\hline & I957 & & 5 & & 2 \\
\hline & 1958 & No & igation neede & & \\
\hline & 1959 & & 9 & & 4 \\
\hline
\end{tabular}

(1955-9) was 3.3 tons/acre, or $40-45 \%$. The mean increase in the West Midland trials was more than 5 tons/acre.

Results obtained at five localities for sugar-beet are summarized by the same authors as quoted in Table 3 .

Work at Reading (Penman, I948) has shown that water alone increased the yields of dry matter by 42 and $36 \%$ respectively in 1955 and 1956 . Recent research has indicated that maximum grass production results from irrigation when the soil moisture deficit reaches about $I$ in.

Table 3. Results of irrigation for sugar-beet (Nix $\&^{\circ}$ Prickett, 1961)

\begin{tabular}{|c|c|c|c|c|c|}
\hline \multirow[b]{2}{*}{ Place } & \multirow[b]{2}{*}{ Year } & \multirow{2}{*}{$\begin{array}{l}\text { Yicld without } \\
\text { irrigation } \\
\text { (sugar, cwt/acre) }\end{array}$} & \multicolumn{2}{|c|}{$\begin{array}{c}\text { Increase in sugar from } \\
\text { irrigation }\end{array}$} & \multirow{2}{*}{$\begin{array}{l}\text { Irrigation } \\
\text { applied } \\
\text { (in.) }\end{array}$} \\
\hline & & & cwt/acre & $\%$ & \\
\hline \multirow[t]{3}{*}{ Milford } & 1947 & 77 & 22 & 29 & $10 \cdot 0$ \\
\hline & I948 & 66 & $\mathbf{I}$ & I & $7 \cdot 6$ \\
\hline & 1949 & 35 & 10 & 29 & $8 \cdot 3$ \\
\hline \multirow[t]{2}{*}{ Kengrave } & 1949 & $3 \mathrm{I}$ & 19 & $6 r$ & $4 \cdot 1$ \\
\hline & 1950 & 55 & 9 & 16 & $2 \cdot 0$ \\
\hline \multirow[t]{9}{*}{ Woburn } & I95 & 50 & 4 & 8 & 3.4 \\
\hline & 1952 & $5 I$ & 8 & 16 & $5 \cdot 6$ \\
\hline & 1953 & 84 & -2 & -2 & 3.6 \\
\hline & 1954 & 45 & 0 & 0 & $x=2$ \\
\hline & I 955 & 34 & I 4 & 41 & 6.4 \\
\hline & 1956 & 64 & -4 & -6 & $1 \cdot 4$ \\
\hline & 1957 & $6 \mathrm{I}$ & $-I$ & -2 & $3 \cdot 6$ \\
\hline & $195^{8}$ & 46 & 0 & 0 & 17 \\
\hline & 1959 & 60 & 28 & 47 & $7 \cdot 3$ \\
\hline \multirow[t]{5}{*}{ Gleadthorpe } & I955 & $18 \cdot 4$ & $45 \cdot 0$ & 244 & 7 \\
\hline & $195^{6}$ & No & ation neede & & \\
\hline & 1957 & $51 \cdot 6$ & $-2 \cdot 0$ & -4 & $\mathbf{I}$ \\
\hline & $195^{8}$ & $50 \cdot 9$ & $5 \cdot 2$ & 10 & 2 \\
\hline & 1959 & $18 \cdot 7$ & $66 \cdot 2$ & 354 & 8 \\
\hline \multirow[t]{2}{*}{ West Midlands } & I957 & $38 \cdot 6$ & $6 \cdot 8$ & 18 & $3 \cdot 1$ \\
\hline & 1959 & $36 \cdot 0$ & 7.0 & $\mathrm{x} 9$ & $4 \cdot 6$ \\
\hline
\end{tabular}


Average yields per acre for irrigated and non-irrigated crops in the seventeen western conterminous states and Louisiana, taken from the US Census of Agriculture for 1959 and from the US Department of Agricultural Statistics for I 962 , are shown summarized in Fig. 2. The national averages for the whole country are also shown. As would be expected, the yields without irrigation are not markedly different from the national averages.

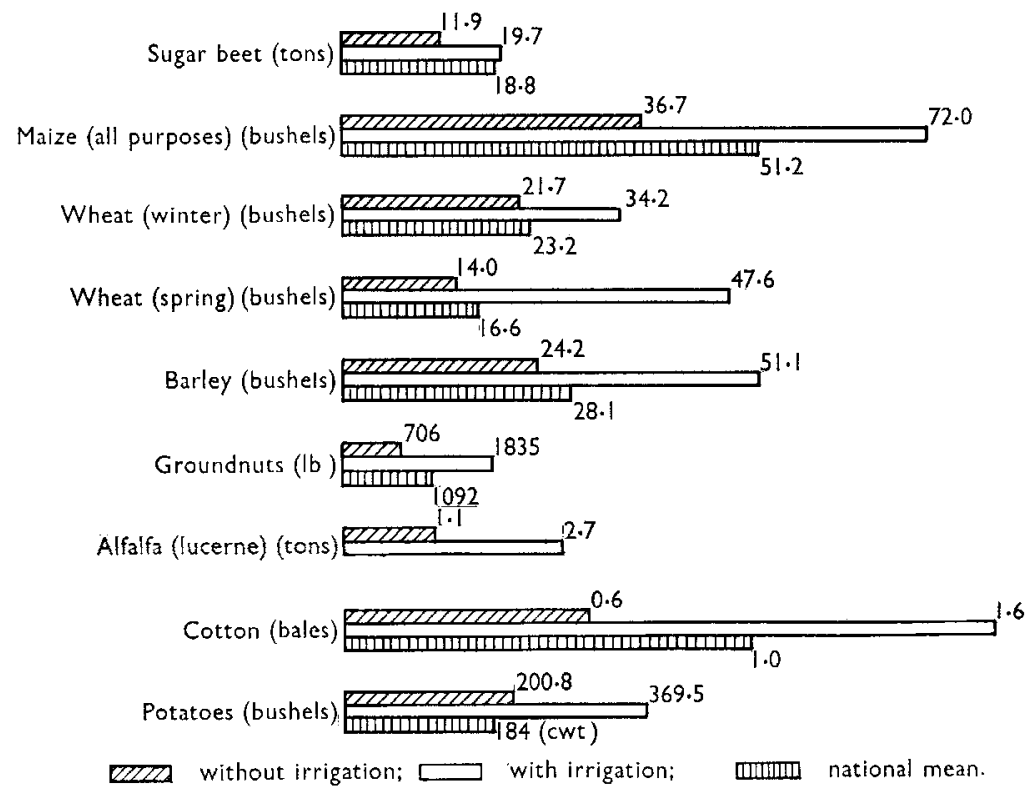

Fig. 2. Mean crop yields in seventeen western conterminous states of USA, I959.

The uncertainties of crop production based on rain-cultivation have been illustrated by Beauchamp (1958) using data from Illinois Agricultural Statistics for yields of maize during the period r900-57 (Fig. 3).

The broad trends of conclusions from accumulating experience may be summarized briefly as follows:

(a) Supplementary irrigation not merely increases yields per acre but stabilizes the entire basis of farming. On a national average basis the yield per acre is approximately doubled when switching from rainfall (dry farm) to supplementary irrigation (Thomas, 1958).

(b) Overall world irrigation efficiencies tend to vary greatly and are generally low, of the order of $30 \%$ (Olivier, 1963 ). The scale of benefits to be derived from increased irrigation efficiencies may be demonstrated by the fact that it is intended to double the existing irrigated areas in the USA by the year 2000 with almost no change in requirements for stored and diverted waters, chiefly by raising the irrigation efficiencies for the eastern and western regions respectively by 10 and $15 \%$. 


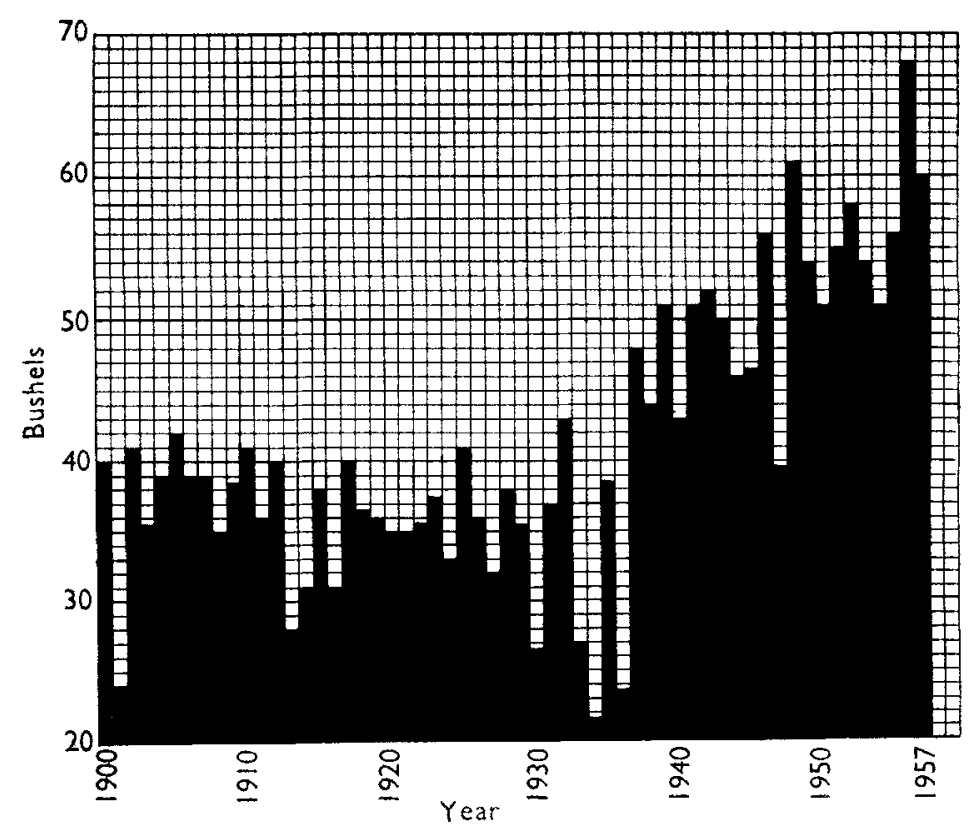

Fig. 3. Mean average maize yields in Illinois.

(Data from Illinois Agricultural Statistics.)

(c) To achieve the desired increase in irrigation efficiencies will require, particularly in most of the developing countries, a well-directed and informed campaign of education to convince farmers of the practical benefits involved. The following is a pertinent extract from a recent statement by the President of the World Bank (Woods, 1964): '. . . The success of our efforts in the fields of agriculture and industry depends in large part, however, on how effectively the initiative, intelligence and skills of the people ... are mobilized for productive purposes . . . somewhere near the root of the process must be education.'

\section{Diet levels in terms of land and water resources}

Optimal combinations of the principal nutrients have not as yet been defined with absolute confidence and the relationship for a given area between any one or all of these and units of cultivated land and of irrigation water is a complex problem.

The most comprehensive and reliable surveys by countries linking nutritive values of food supplies with populations and cultivated areas are carried out regularly by the Food and Agriculture Organization of the United Nations, and draw attention to serious limitations in the preparation of such international balance sheets. A particularly serious defect for purposes of comparative reviews is that food balance sheets estimate average per caput needs and supplies and do not reveal the variation of standards within the populations. 
However, the calorie standards provided by FAO are generally accepted by nutritionists, and the reviews which follow have been based on their latest (FAO, r 962) statistics for diet levels in terms of calories, these being judged the best available means for estimating total extra food needed in particular countries to maintain or reach specified standards of nutrition.

Recent projections between 1962 and 1966 by West (1962) lead to the conclusion that food problems centre primarily in the Far East and in Communist Asia where the dense and growing populations press increasingly on the food supply. Thus the Free Far East has two-thirds of the wheat shortage projected for $1962-6$ and nearly one-half of the animal and pulse protein and fat deficit. This region represents $42 \%$ of the population of the regions with diet deficit and has $60 \%$ of the deficit. Communist Asia has most of the rest of the animal protein and fat shortage and, in spite of large purchases of grain, still has a large calorie gap.

Considerable research is necessary before it will be possible to establish reliable links between nutrient yields per acre in terms of irrigation supplies. Among factors exerting an influence on such a relationship are the different ratios between food plus forage and fibre crops grown in a particular area, the extent of fallow adopted, length of growing season, the extent of double cropping per acre (as in Pakistan and Egypt) and the relative importance of calorie, protein and fat nutrients and the agricultural and irrigation efficiencies practised in different countries.

\section{Review of selected countries in terms of food potential in relation to land and water resources}

A few countries have been selected for brief review primarily to illustrate contrasts of problems and potentials. It has been assumed that, irrespective of the cultivation of fibre or cash crops, the total cultivated areas, with minor exceptions, do bear a general relationship to calorie requirements per caput. For purposes of calculating gross effective acres, the yield from an irrigated acre has been taken as twice that of a dry-farmed acre.

Egypt. Egypt is selected because it is the best example of a country with negligible effective rainfall, and thus entirely dependent on irrigation agriculture, and the question of supplementary irrigation supplies does not arise. Water resources are

Table 3. Diet levels in relation to existing and projected cultivated and irrigated areas in Egypt

\begin{tabular}{lrc}
\multicolumn{1}{c}{ Description } & $196 \mathrm{I}$ & 2000 \\
Population $\left(\mathrm{IO}^{-6}\right)$ & $26 \cdot 6$ & $56 \cdot 0$ \\
Arable land cultivated (acres $\times \mathrm{IO}^{-6}$ ) & $6 \cdot \mathrm{I}$ & $8 \cdot 4^{*}$ \\
Total area irrigated (acres $\left.\times \mathrm{IO}^{-6}\right)$ & $6 \cdot \mathrm{I}$ & $8 \cdot 4 \dagger$ \\
Mean national daily food supply (kcal/head) & 2530 & $1800{ }^{\circ}$
\end{tabular}

\footnotetext{
*Total area available for cultivation has been given as 7.6 million acres but, allowing for intensified farming, the total is brought up to 8.4 million acres.

+Completion of the High Aswan (Sadd-el-Aali) dam in the near future will provide some 56 million acre-feet of guaranteed net draft from storage, sufficient to irrigate 7 million acres, of which 2 million are said to be in Egypt (Selim, I958).

$\ddagger$ Minimum diet standards for the region taken as $2400 \mathrm{kcal} / \mathrm{head}$ daily.
} 
limited-almost the entire irrigation supplies being imported from Ethiopia, Sudan, and East Africa via the Nile. The projections are summarized in Table 3.

The inference is that well before the year 2000 population pressures will be such that either a drop in nutritional levels to below minimum standards will have to be accepted or irrigation will have to be extended up to the presently known limits of water resources. In order to maintain present nutritional standards it will be necessary to irrigate at least another 6.0 million acres, i.e. a total of 12.0 million acres.

Apart from whether cultivable and irrigable land is available, doubts about longterm availability of water, having regard to projected upstream developments and the depletion of reservoir storage from siltation, will increase the pressures for 'common market' policies. Whether this takes the form of establishment of regional collaboration areas for import and export facilities or a revival of the idea of 'century' storage, whereby the Nile waters are stored usefully and economically in the vast reservoir potentials of East Africa and Ethiopia, are matters of conjecture.

Sudan. Conditions in Sudan are interesting, by comparison with Egypt, on account of the greater availability of land and water resources. Review projections are summarized briefly in Table 4 .

Table 4. Diet levels in relation to existing and projected cultivated and irrigated areas in the Sudan

$\begin{array}{lcc}\quad \text { Description } & 1960 & 2000 \\ \text { Population }\left(10^{-6} \text { ) }\right. & 12 \cdot 1 & 25.0 \\ \text { Arable land under cultivation (acres } \times 10^{-6} \text { ) } & 17 \cdot 5^{*} & 25 \cdot 0 \dagger \\ \text { Total area irrigated (acres } \times 10^{-6} \text { ) } & 2 \cdot 0 & 4.57 \\ \text { Mean national daily diet level (kcal/head) } & 2500 & 2500\end{array}$

*Agricultural practice at present is based on a considerable proportion of cultivated land lying fallow. †The gross cultivated area, before allowing for irrigation, is calculated on the basis of more intensified and efficient farming. Potential additional available land is given by FAO (1962) at 94 million acres.

†According to a recent survey of irrigable areas carried out for the Sudan Government (Sir Alexander Gibb \& Partners, 1954, Report to Sudan Government, unpublished) there are I.7 million additional irrigable acres available within the limited areas covered by the terms of reference. Thus there should be no difficulty in achieving the target of 2.5 million acres of additional irrigation indicated. Water resources from the Blue and White Niles are adequate. It has been estimated that at Ieast $46 \%$ of the flow of the White Nile at present lost in the Sudd (Bahr-el-Jebel) region could be reclaimed, which by itself would be sufficient to irrigate some 6 million acres (Hurst \& Phillips, 1938).

The inference is that, with increased irrigation, the agricultural potential is adequate, not merely to maintain nutritional standards but to produce surpluses.

India. Review projections are summarized briefly in Table 5 and compared with similar projections for West Pakistan in Table 6.

West Pakistan. The review is confined to West Pakistan because conditions in East Pakistan are generally very similar to those of India.

In order to achieve the target of bringing nutrition levels up to minimum standards for the region, both India and West Pakistan will need to make the utmost use of water and land resources. The problem is far greater in India than in Pakistan as some 40 million acres of additional perennial irrigation will have to be achieved there in comparison with 15 million in West Pakistan. 
Table 5. Diet levels in relation to existing and projected cultivated and irrigated areas in India

\begin{tabular}{lcc}
\multicolumn{1}{c}{ Description } & 1960 & 2000 \\
Population $\left(10^{-6}\right)$ & 442 & 670 \\
Arable land under cultivation (acres $\left.\times 10^{-6}\right)$ & $400^{*}$ & $45 \mathrm{I}$ \\
Area irrigated (some double-cropped) $\left(\mathrm{acres} \times 10^{-6}\right)$ & 58 & $109 \dagger$ \\
Mean national daily diet level (kcal/head) & 2040 & 2300 \\
Potential additional cultivable land available (acres $\times 10^{-6}$ ) & $5 \mathrm{I} \ddagger$ & -
\end{tabular}

\footnotetext{
*Assumed subdivision: 342 million acres dry-cropped; 35 million acres perennial irrigation; 23 million acres irrigated by floods, wells, and the like.

$\uparrow I t$ is assumed that additional areas are irrigated by perennial canals, and that supplementary irrigation is extended to all existing areas. Irrigation efficiency increased by $10 \%$.

†The Rajashtan canal now under construction is designed to command 3.4 million acres.
}

Table 6. Diet levels in relation to existing and projected cultivated and irrigation areas in West Pakistan

$\begin{array}{lrr}\quad \text { Description } & 1960 & 2000 \\ \text { Population }\left(\mathrm{IO}^{-6}\right) & 43 & 65 \\ \text { Total cropland cultivated (acres } \times 10^{-6} \text { ) } & 39 & 47 \\ \text { Perennial irrigation (canals) (acres } \times 10^{-6} \text { ) } & 17^{*} & 32 \dagger \\ \left.\text { Seasonally irrigated (floods, wells and the like) (acres } \times 10^{-6}\right) & 14 & 7 \\ \text { Dry-cropped (acres } \times 10^{-6} \text { ) } & 8 & 8 \\ \text { Mean national daily diet level (kcal/head) } & 1970 & 2300\end{array}$

*Area double-cropped: Rabi (summer) and Kharif (winter).

It is assumed that irrigation efficiencies increase by at least $10 \%$ and that supplementary irrigation water can be made available to at least 7 million acres.

In West Pakistan it is estimated that some 60 million acre-feet of water will be required to achieve the irrigation targets. Storage capacities on the Indus and Jhelum tributaries have been estimated at approximately 88 million acre-feet and at present the average quantity of waters wasted to sea from the Indus system is between 60 and 70 million acre-feet (Tipton, 1954). Thus, the potential would appear to be there, but it will be a costly task to provide the storage reservoirs required because for reasons of topography and geology dam sites are not readily available. The costs of storage projects currently being constructed under the Indus Basin Fund Agreement work out at approximately $£ 40$ per usable acre-foot, which is very expensive by world standards. There is available a considerable reservoir of underground storage, but despite some very optimistic reports by various authorities the problems of mining this source in relation to salinity and other problems have by no means been solved.

In both countries irrigation is the key to maintenance or improvement of nutritional standards, but of the two the indications are that the pressures towards 'regional co-operative arrangements' will be felt in India sooner and to a greater extent than in West Pakistan.

$U S A$. The records of the USA provide the best working examples for projection of food supply problems in relation to agricultural resources and irrigation factors. 24 (I) 2 
Agriculturally the country is self-sufficient and statistics of food production in relation to cultivated acreage are more meaningful than for many other countries.

The evolution process of irrigation practice in the USA is entering a new phase. The rate of explosive expansion of full-time (arid) irrigation of the west is slowing down owing to decreasing availability of water due to physical exhaustion and competitive demands from industrial and other enterprises. On the other hand, the rate of part-time (peak or supplementary) irrigation is increasing rapidly to realize the benefits from stabilizing and increasing the agricultural output with particular reference to the optimum production per unit of water at source.

Existing and projected conditions have been summarized in Table 7 .

\section{Table 7. Diet levels in relation to existing and projected cultivated and irrigated areas} in the USA

$\begin{array}{lrr}\quad \text { Description } & 1960 & 2000 \\ \text { Population low projection }\left(10^{-6}\right) & 184 & 262 \\ \text { Population high projection }\left(10^{-6}\right) & 184 & 31 \text { I } \\ \text { Mean national daily food supply: low projection (kcal/head) } & 3100 & 2600^{*} \\ \text { Mean national daily food supply: high projection }(\mathrm{kcal} / \mathrm{head}) & 3100 & 3100 \\ \text { Gross area cultivated: low projection }\left(\text { acres } \times 10^{-6}\right) & 455 & 520 \\ \text { Gross area cultivated: high projection }\left(\text { acres } \times 10^{-6}\right) & 455 & 740 \\ \left.\text { Area irrigated: low projection (acres } \times 10^{-6}\right) & 41 & 65 \\ \left.\text { Area irrigated: high projection (acres } \times 10^{-6}\right) & 41 & 280\end{array}$

* Minimum daily diet standard for the region.

Adopting a medium projection it would appear that self-sufficiency and adequate diet levels can be maintained by the year 2000 with an irrigated area of 200 million acres and a dry-farmed area of 250 million acres. There is room for considerable improvement of national average agricultural efficiencies since the use of fertilizer per unit of land in the USA is still low in comparison with countries such as the Netherlands and Japan.

As regards land resources it is estimated that gain and loss may be balanced by 2000 and it would therefore not be prudent to assume that the overall national total land cultivated will increase materially. As regards water resources the additional requirements of 178 million acre-feet are estimated to be well within the national resources. A recent estimate (Boyer, I 960 ) has shown that projections of total water requirements by 2000 will amount to approximately $50 \%$ of total available supplies, on the assumption that the bulk of the increased irrigation is achieved by conversion from dry-farm to irrigation cultivation.

Western Europe. Brief reference to Western Europe, where irrigation is not practised on a large scale, is nevertheless interesting because of a number of factors. Despite the relatively higher average national agricultural yields per acre compared with the USA, due to the better seasonal and geographical distribution of rainfall, greater fertility of soils, and more intensive use of fertilizers, total land and water resources are not sufficient for countries like the United Kingdom and Netherlands, for instance, to be self sufficient in agricultural production. 
For the UK an approximate assessment of production in relation to nutrition standards, land, and water resources shows that without irrigation the ratio of required to available cultivated acreage is of the order of $80: 18$, approximately $4: \mathrm{I}$. This may be taken as an indication of the propellant force towards making regional arrangements for agricultural import facilities.

Even if the entire available area now cultivated were to be irrigated with supplementary waterings--estimated at I 8 million acre-feet--the shortfall ratio would only be reduced to approximately $2: \mathrm{I}$, but would increase again to $2 \cdot 6:$ I by the year 2000 on account of population growth.

Conditions for countries like the Netherlands are similar.

France, on the other hand, is almost self-sufficient agriculturally and, with 53 million cultivated acres (as yet relatively little irrigation is practised) supports a population of 45 million at a national daily diet level of $2990 \mathrm{kcal} / \mathrm{head}$. Projected requirements in the year 2000 could be met by introducing only 7 million acres of irrigated cultivation.

Mainland China. The fact that China already has the greatest irrigated acreage in the world does not mean that the potential is extensible in a material sense. Limiting factors are the geographical distribution of water resources and the ratio of mountainous lands to plains (cultivable). Bearing in mind its ancient civilization and an irrigation history of many centuries, it is significant that the total area presently cultivated represents only i $\%$ of the total land area-compared with $23 \%$ in the USA - but that the total area irrigated already represents $68 \%$ of the total cultivated area, compared with $7 \%$ in the USA, and that the national average daily diet level is assessed at $1900 \mathrm{kcal} / \mathrm{head}$ compared with a minimum desirable standard for the region of 2300 .

It is estimated that, even if by the year 2000 irrigation efficiencies could be improved by $10 \%$ and could be extended to the entire area at present cultivated, together with one-third of the area at present used as meadows or forested, the mean national daily diet level would only be raised to $2000 \mathrm{kcal}$, i.e. a deficiency of $300 \mathrm{kcal} / \mathrm{head}$ (Table 8 ).

Table 8. Diet levels in relation to existing and projected cultivated and irrigation areas in mainland China

\begin{tabular}{lrr}
\multicolumn{1}{c}{ Description } & 1960 & 2000 \\
Population $\left(10^{-6}\right.$ ) & 640 & 1380 \\
Mean national daily diet level (kcal/head) & 1900 & 2000 \\
Area cultivated (acres $\times 10^{-6}$ ) & 270 & 453 \\
Area irrigated (acres $\left.\times 10^{-6}\right)$ & 183 & 453
\end{tabular}

If, as assumed above, it were possible to irrigate all the cultivable areas (which is obviously not feasible) a measure of the outward pressure towards self-sufficiency would be reflected by the ratio of $80 \%$ representing potential in relation to requirements. Another recent estimate has put this ratio as low as $43 \%$ (Boyer, 1960). 


\section{Summary and outlook}

Reviews of this nature highlight in the first place the extent to which recent technological advances have outstripped the capacity for practical application on account of insufficient or unreliable basic data. Achievement of reliable assessments of world potential in relation to food and forage production and requirements and of the desirable higher irrigation efficiencies is dependent on advances to be made under the following major headings :

(a) Extension of soil surveys. At present less than $10 \%$ of the world's area is reliably mapped as regards soil surveys for agricultural purposes. This lack is particularly true of the diet-deficient regions of the Far East and the area of relatively unexplored potential: Africa and South America.

(b) Reorganization of meteorological observations. The records as currently observed on a global basis, with particular reference to rainfall, make it very difficult, if not impossible, to make proper assessment of effective rainfall and hence to evaluate criteria for the extension of supplementary irrigation in fertile moist regions.

(c) Compilation and correlation of statistical data relating nutrition yield levels to units of land and water by regions and soil types.

(d) Dissemination to the masses of farmers and farm workers in simple practical terms and demonstration of the advantages accruing from improved practices.

On the basic data available the present 'food-adequate' areas are located mainly in the temperate zones covering Europe, North America, USSR, Oceania, the southern part of Africa and the eastern parts of South America. The diet-deficient regions include Communist Asia, the rest of the Far East, western parts of South America and most of the northern part of Africa, and involve about two-thirds of the world's population. These are also the regions which account for more than $80 \%$ of current irrigation practice. Thus irrigation by itself has been a major factor up to now in holding at bay the spectre of mass famines in these regions. Unfortunately, centuries of intense and agriculturally inefficient soil exploitation have reduced yields per units of land and water, and therefore nutrient levels. The first remedial measures in the developing territories will therefore have to be better agricultural practices: tillage, use of fertilizers, improved seeds and more efficient use of water in relation to climate. There is precedent for this in that it is only since World War II that expansion of agricultural production and negotiable manufactures brought Mediterranean Europe, Eastern Europe (including Russia) and Japan into the 'food-adequate' category.

These reviews indicate that some regions can never be self-sufficient, others not now self-sufficient can become so, and others will remain self-sufficient agriculturally at least for the period projected-up to 2000 . Refinements of such reviews may therefore serve to indicate the need for regional associations which would make the whole self-sufficient. Whether such arrangements are effected peacefully or otherwise is a matter of statesmanship and politics.

In the vast unexplored areas of Africa and South America the water supplies have hardly been tapped. With the exception of the Nile, the water wealth of great African 
rivers like the Congo, Rufiji, Zambesi and Orange still flows to sea virtually unutilized. As soil surveys proceed it will be possible, in the light of present scientific knowledge, to classify as arable large areas of land previously rejected as unsuitable.

Once soil mapping of the world is adequate and meteorological observations made meaningful in an agricultural sense, it should be possible to accelerate exploration of the possibilities and economics of development of agricultural zones for world food production, with particular reference to supplementary irrigation. If the same, or better yields can be obtained in a humid zone with an application of $\mathrm{I} f \mathrm{ft}$ of water as that from applications of $3 \mathrm{ft}$ in an arid zone, the implications, by all standards, become obvious. In the meantime, no country with adequate water resources, whether self-sufficiency is ultimately attainable or not, can afford not to irrigate. The agricultural efficiencies achieved in countries like the Netherlands and the UK are examples of target standards.

\title{
REFERENCES
}

Beauchamp, K. H. (1958). Proc. Amer. Soc. civ. Engrs, 84, Paper 1750.

Boyer, M. C. (1960). F. Irr. Drge Div. Proc. Amer. Soc. civ. Engrs, 86, Paper 2593.

FAO (1962). FAO Prod. Yearb. I6.

Gulhati, N. D. (1958). Proc. Amer. Soc. civ. Engrs, 84, Paper 175I.

Hurst, H. E. \& Phillips, P. (1938). Nile Basin, 5. Cairo Government Press.

Kutilla, J. V. \& Eckstein, O. (1957). Multiple Purpose River Development-Studies in Applied Economic Analysis. Baltimore: Johns Hopkins Press.

McKean, R. N. (1958). Efficiency in Government through Systems Analysis, with Emphasis on Water Resource Development (Publications in Operations Research no. 3). New York: John Wiley \& Sons Inc.

Nix, J. S. \& Prickett, C. N. (1961). Rep. Frm Econ. Camb. Univ. no. 55.

Olivier, H. (1963). 5th Congr. int. Comm. Irrig. \& Drge, Tokyo. Question 16.

Penman, H. L. (1948). Proc. roy. Soc. A, 193, 120.

Selim, M. A. (1958). Civ. Engng, Lond., 55, 59 I.

Thomas, R. O. (1958). F. Irr. Drge Div. Proc. Amer. Soc. civ. Engrs, 84, Paper 1754.

Tipton, R. J. (1954). Annu. Conv. Amer. Soc. civ. Engrs, Washington, D.C.

West, Q. M. (1962). Food-One Tool in International Economic Development. Iowa State University Center Agric. Econ. Adjustment.

Woods, G. (1964). Speech at U.N. Conf. Trade and Development, Geneva. Geneva: International Bank for Reconstruction and Development.

\section{Soil and plant nutrient content in relation to crop yield}

\author{
By C. Bould, Long Ashton Research Station, University of Bristol
}

\section{Introduction}

Plant growth and crop yield are conditioned by two sets of factors: (1) the external factors such as light, temperature, water, nutrient supply, management and the incidence of pests and diseases and (2) internal factors, mainly nutritive but also hormonal. This paper is concerned generally with the inorganic nutrition of plants growing in soil, and more specifically with factors that affect soil nutrient availability and plant nutrient uptake, and with the relationship between plant nutrient content and crop yield. 